Review Article

\title{
采
}

\section{Nurse competencies for health promotion in the mental health context}

\author{
Competências do enfermeiro para promoção da saúde no contexto de saúde mental \\ Competencias del enfermero para la promoción de la salud en el contexto de la salud mental
}

\begin{abstract}
Maria Isis Freire de Aguiar ${ }^{1}$, Hélder de Pádua Lima ${ }^{2}$, Violante Augusta Batista Braga $^{3}$, Priscila de Souza Aquino ${ }^{4}$, Ana Karina Bezerra Pinheiro ${ }^{5}$, Lorena Barbosa Ximenes $^{6}$
\end{abstract}

\begin{abstract}
Objective: To identify the competencies of nurses to health promotion in psychiatric and mental health context. Methods: Integrative review of literature performed through search using the keywords: "mental health" and "professional competence", in the databases SciELO, LILACS, CINAHL, PubMed, Scopus and Cochrane, in the period of 2003 to 2011.215 studies were identified, of these, six followed the inclusion criteria. Results: Based on the National Panel for Psychiatric Mental Health NP Competencies, the competencies were identified on the evaluated studies: Monitoring and ensuring the quality of health care practice, management of patient health/illness status, cultural competence, managing and negotiating health care delivery systems, the nurse practitioner-patient relationship. Conclusion: The studies analysis evidenced the need for education and training so that nurses may develop the competencies of health promotion in diverse psychiatric care and mental health contexts, in order to broaden knowledge and skills.
\end{abstract}

Keywords: Mental health; Professional competence; Nursing

\section{RESUMO}

Objetivo: Identificar as competências do enfermeiro para promoção da saúde no contexto psiquiátrico e de saúde mental. Métodos: Revisão integrativa da literatura realizada por meio da busca com os descritores controlados: "mental health" e "professional competence", nas bases de dados SciELO, LILACS, CINAHL, PubMed, Scopus e Cochrane, no período entre 2003 e 2011. Foram identificados 215 artigos, dos quais seis atenderam aos critérios de inclusão. Resultados: Com base no National Panel for Psychiatric Mental Health NP Competencies, as competências foram identificadas nos estudos avaliados: Controle e garantia da qualidade dos cuidados de saúde; Gestão de doença do paciente; Competência cultural; Gestão e negociação dos sistemas de saúde e Relação Enfermeiro-Paciente. Conclusão: A análise dos estudos evidenciou a necessidade de formação e capacitação dos enfermeiros para desenvolverem as competências de promoção da saúde nos diversos contextos da atenção psiquiátrica e de saúde mental, com vistas a ampliar conhecimentos e habilidades necessárias.

Descritores: Saúde mental; Competência profissional; Enfermagem

\section{RESUMEN}

Objetivo: Identificar las competencias del enfermero para la promoción de la salud en el contexto psiquiátrico y de salud mental. Métodos: Revisión integrativa de la literatura realizada por medio de la búsqueda con los descriptores controlados: "mental health" y "professional competence", en las bases de datos SciELO, LILACS, CINAHL, PubMed, Scopus y Cochrane, en el período comprendido entre 2003 y 2011. Fueron identificados 215 artículos, de los cuales seis atendieron a los criterios de inclusión. Resultados: Con base en el National Panel for Psychiatric Mental Health NP Competencies, las competencias fueron identificadas en los estudios evaluados: Control y garantía de la calidad de los cuidados de salud; Gestión de la enfermedad del paciente; Competencia cultural; Gestión y negociación de los sistemas de salud y Relación Enfermero-Paciente. Conclusión: El análisis de los estudios evidenció la necesidad de formación y capacitación de los enfermeros para desarrollar las competencias de promoción de la salud en los diversos contextos de la atención psiquiátrica y de salud mental, con vistas a ampliar conocimientos y habilidades necesarias. Descriptores: Salud mental; Competencia profesional; Enfermería

\footnotetext{
1 Assistant Professor, Federal University of Maranbao - UFMA, São Luis (MA), Brazil.

${ }^{2}$ Graduate student in Nursing (PhD), Federal University of Ceara - UFC, Fortaleza (CE), Brazil.

${ }^{3}$ Associate Professor of Nursing Department, Federal University of Ceara - UFC, Fortaleza (CE), Brazil.

${ }^{4}$ PhD in Nursing. Postdoctoral fellowship, Federal University of Ceara - UFC, Fortaleza (CE), Brazil.

${ }^{5}$ Associate Professor, Federal University of Ceara - UFC, Fortaleza (CE), Brazil.

${ }^{6}$ Associate Professor, Federal University of Ceara - UFC, Fortaleza (CE), Brazil.
} 


\section{INTRODUCTION}

In Western history since the end of World War II, significant movements of Psychiatric Reform emerged in countries like France, England, Italy, USA, Canada and Spain, contributing to the advancement of mental health care and the transformation of health care models in this field. Although there are obvious differences in their historical, social and political contexts, denounces of the asylum situation and the efforts to overcome it were common to all of these models ${ }^{(1)}$.

Currently, the World Health Organization has developed an organizational model that proposes the integration of mental health services with health care in general, in which the integrated primary care in mental health is a key component of this model, supported by other levels of care, including community-based and hospital services. Regardless of the resources level, all countries should seek to obtain the best possible combination of services at all levels and regularly assess their available structure ${ }^{(2)}$.

Despite the notorious advances that came with the Psychiatric Reform, authors state that, in Brazil, it is still common in mental health services the implementation of traditional practices, with the fragmentation of care, the medical centrality in decision making and the hegemony of psychiatric knowledge about care ${ }^{(3)}$.

Facing the advances and changes in the Psychiatric Reform, the actions of field professionals should focus on the mental health of individuals in psychological suffering, focusing in health promotion, encouraging the reconstruction of citizenship, social reintegration and autonomy of these individuals.

The Ottawa Charter brings the concept of health promotion which is still currently accepted, as a process of empowering people and communities to increase control over the determinants of health and improve their health ${ }^{(4)}$. It is understood, therefore, the importance of the relationship between health promotion and mental health with regard to the need for autonomy of the individual in psychological suffering, providing opportunities that empower them to make choices, participating as the protagonist in the production of their care.

The consolidation of this process presents challenges that go beyond the ideological and political advances made, there is a need for qualifying professionals with critical thinking capacity, essential to sustain a health care practice that is constituted, as an act of transformation for all involved: patients, professionals and involved social networks ${ }^{(5)}$.

Given this reality, nurses working in psychiatric care and mental health need to develop necessary competencies for the practice of health promotion and effectively confront the current challenges. In 1990, The American Association of Colleges of Nursing, developed a set of domains and competencies, updated and revised in 1995 and 2000, being published in 2003 a document, endorsed by the International Society of Psychiatric Mental Health Nurses with the core competencies for nurses in the psychiatric/mental health context ${ }^{(6)}$.

Although the document is not recognized as an international guideline, it will serve as a basis for comparison of this research findings, considering relevant to discuss how professionals are working in this care model and if they are developing these competences in professional practice. In this regard, this study was performed in order to identify the competencies of nurses to health promotion in psychiatric and mental health context.

\section{METHODS}

This is an integrative review of the literature which provides a synthesis of the knowledge on the investigated topic and the incorporation of the applicability of the results of significant studies in practice, being an important instrument of Evidence-Based Practice ${ }^{(7)}$.

The research was conducted guided for the following steps: preparing the research question, search or sampling the literature, data collection, and critical appraisal of the included studies, discussion of the results and presentation of the integrative review. The study emerged from the question: What are the competencies used in nursing practice in the psychiatric and mental health context for health promotion?

For the selection of studies, the used keywords were: mental health, professional competence, simultaneously crossed in the databases: SciELO, LILACS, CINAHL, PubMed, Scopus and Cochrane. The inclusion criteria for studies were: original articles, available in full text, in Portuguese, English or Spanish, published since 2003, year of publication of the document concerning nurses competencies in the mental health and psychiatric context.

Exclusion criteria were: Studies without abstract, literature reviews, editorials, final course paperwork, dissertations, theses and letters.

The studies were selected for evaluation through the titles and abstracts available, with a total of 216 studies. After their full reading, we excluded 30 reviews, 06 with only abstract available, 01 in German, 171 studies related to other topics and 02 with publication year prior to 2003, therefore 06 studies that met the inclusion criteria were selected.

Data collection was conducted by two $\mathrm{PhD}$ students in Nursing, trained during Course classes, besides training through the Portal of the Coordination of Improvement of Higher Education (CAPES). 
The instrument was developed by the authors and submitted to two experts in the field. It comprises characteristics of the studies, actions performed, results and a check-list based on seven domains of competencies of the psychiatric and mental health nurse context: 1.Management of patient health/illness status; 2 . The nurse practitioner-patient relationship; 3 . The teachingcoaching function; 4.Professional role; 5.Managing and negotiating health care delivery systems; 6 . Monitoring and ensuring the quality of health care practice; 7.Cultural competence ${ }^{(6)}$.

The studies were classified according to the hierarchy of evidence as follows: Level 1: evidence from meta-analysis of multiple randomized controlled trials, level 2: evidence from individual studies with experimental design; Level 3: evidence from quasi-experimental studies, Level 4: evidence from descriptive studies (non-experimental) or with qualitative approach; Level 5: evidence from case reports or experience ${ }^{(7)}$.

Data were organized in tables, based on the synthesis of studies and competencies identified. The analysis was performed descriptively, proceeding to compare the actions performed with the recommended competencies for practice in psychiatric care and mental health nurses, and the discussion was based on comparison with other studies related to the topic.

\section{RESULTS}

The synthesis of the studies was presented in the data in Table 1. Information related to the competencies of psychiatric and mental health nurses were identified in studies presented in the data of Table 2 .

Table 1. Summary of studies on the competencies of psychiatric and mental health nurses

\begin{tabular}{|c|c|c|c|c|}
\hline Study & Method & Actions Performed & Results & Conclusions/Limitations \\
\hline Hurley et al. ${ }^{(8)}$ & Not especified & $\begin{array}{l}\text { Identifying the } \\
\text { competencies of mental } \\
\text { health nurses; educational } \\
\text { training. }\end{array}$ & $\begin{array}{l}\text { There was an increase in knowledge, } \\
\text { confidence and capacity, with the } \\
\text { ability to assess and respond to } \\
\text { people at risk showing the highest } \\
\text { increase. }\end{array}$ & $\begin{array}{l}\text { In the specific context of the } \\
\text { project, an important mechanism } \\
\text { seems to be reflected in policy } \\
\text { objectives for clinically relevant } \\
\text { education and training. }\end{array}$ \\
\hline $\begin{array}{l}\text { Elsom, } \\
\text { Happell, } \\
\text { Manias }^{(9)}\end{array}$ & $\begin{array}{l}\text { Correlational } \\
\text { cross-sectional } \\
\text { study }\end{array}$ & $\begin{array}{l}\text { Prescription and } \\
\text { adjustment of doses of } \\
\text { medication; diagnostic tests } \\
\text { request; refer patients to } \\
\text { specialists physician; make } \\
\text { recommendations for } \\
\text { treatment; writing medical } \\
\text { certificates. }\end{array}$ & $\begin{array}{l}\text { It was found that mental health } \\
\text { nurses in the community have } \\
\text { the confidence to make expanded } \\
\text { practice roles, and they recognize the } \\
\text { need for education and experience. }\end{array}$ & $\begin{array}{l}\text { It is necessary to develop a } \\
\text { systematic approach to education } \\
\text { and pressure from the government } \\
\text { and other policy makers to } \\
\text { overcome barriers and ensure the } \\
\text { potential benefits of expanding } \\
\text { roles. }\end{array}$ \\
\hline $\begin{array}{l}\text { Quintero, } \\
\text { Lilliott, } \\
\text { Willging(10) }\end{array}$ & $\begin{array}{l}\text { Qualitative } \\
\text { study }\end{array}$ & $\begin{array}{l}\text { Information to support the } \\
\text { development of culturally } \\
\text { relevant care to rural } \\
\text { population of adolescents. }\end{array}$ & $\begin{array}{l}\text { Lack of family integration, } \\
\text { religion, dominant male culture } \\
\text { and socioeconomic factors had } \\
\text { an impact on substance abuse in } \\
\text { adolescents. }\end{array}$ & $\begin{array}{l}\text { Recommendations for training } \\
\text { providers with a focus on cultural } \\
\text { issues in ways that can critically } \\
\text { consider their ideas about culture. }\end{array}$ \\
\hline $\begin{array}{l}\text { McLindon, } \\
\text { Harms }^{(11)}\end{array}$ & $\begin{array}{l}\text { Exploratory } \\
\text { study }\end{array}$ & $\begin{array}{l}\text { Caring for women who } \\
\text { have suffered sexual abuse }\end{array}$ & $\begin{array}{l}\text { Half of the professionals did not } \\
\text { feel well prepared to respond to a } \\
\text { situation of sexual abuse and rarely } \\
\text { referred women to specialized } \\
\text { centers. }\end{array}$ & $\begin{array}{l}\text { Recommendations for training and } \\
\text { increasing communication between } \\
\text { mental health systems and sexual } \\
\text { abuse service to ensure best results. }\end{array}$ \\
\hline $\begin{array}{l}\text { Kim, } \\
\text { Salyers }^{(12)}\end{array}$ & $\begin{array}{l}\text { Descriptive } \\
\text { study }\end{array}$ & $\begin{array}{l}\text { Emotional support; } \\
\text { counseling; information } \\
\text { about the disease; discussion } \\
\text { of plans with family and } \\
\text { inclusion in planning; } \\
\text { guidance of services; conflict } \\
\text { mediation; reference to } \\
\text { support groups; family } \\
\text { therapy }\end{array}$ & $\begin{array}{l}\text { The total level of services provided } \\
\text { to families was low. The types of } \\
\text { services most frequently reported } \\
\text { were: emotional support, practical } \\
\text { advices on how to handle specific } \\
\text { situations and information about } \\
\text { mental illness and client progress, } \\
\text { discuss future plans for the client. }\end{array}$ & $\begin{array}{l}\text { Given the serious nature of severe } \\
\text { mental illness, its impact on the } \\
\text { family and the responsibility for } \\
\text { the care that families continue } \\
\text { supporting, it is necessary to create } \\
\text { alliances between mental health } \\
\text { professionals and families, assisting } \\
\text { in care functions. }\end{array}$ \\
\hline $\begin{array}{l}\text { Akerjordet, } \\
\text { Severinsson }^{(13)}\end{array}$ & $\begin{array}{l}\text { Hermeneutics } \\
\text { qualitative } \\
\text { approach }\end{array}$ & $\begin{array}{l}\text { Relationship with the } \\
\text { patient and supervision }\end{array}$ & $\begin{array}{l}\text { On the significance of the } \\
\text { relationship, the partnership with } \\
\text { the patient suffering from mental } \\
\text { health problems is central, including } \\
\text { authentic partnership, consciousness } \\
\text { of intuition, understanding and social } \\
\text { abilities. The supervision was an } \\
\text { important and positive factor in the } \\
\text { mental health environment. }\end{array}$ & $\begin{array}{l}\text { Emotional intelligence stimulates } \\
\text { the search for a deeper } \\
\text { understanding of a professional } \\
\text { identity. Emotional learning } \\
\text { and maturation processes are } \\
\text { fundamental to professional } \\
\text { competence. }\end{array}$ \\
\hline
\end{tabular}


Table 2. Competencies identified in the actions of nurses, according to studies analyzed

\begin{tabular}{|lll|}
\hline $\begin{array}{l}\text { Monitoring and ensuring quality of } \\
\text { health care practice }\end{array}$ & Management of patient health/illness status & Cultural competence \\
\hline $\begin{array}{l}\text { Evaluates the coordinated response } \\
\text { in development of unplanned care } \\
\text { services for mental health }^{(8)}\end{array}$ & $\begin{array}{l}\text { Identifies confidence and preparation of community } \\
\text { mental health nurses when performing expanded roles }{ }^{(9)}\end{array}$ & $\begin{array}{l}\text { Identifies cultural factors that } \\
\text { contributed to substance abuse }_{\text {in adolescents }}{ }^{(10)}\end{array}$ \\
& $\begin{array}{l}\text { Explores how mental health workers and respond to } \\
\text { women who reveals sexual abuse in the scenario of crisis } \\
\text { service }\end{array}$ & $\begin{array}{l}\text { Professionals identify } \\
\text { cultural barriers of women in } \\
\text { attendance }^{(11)}\end{array}$ \\
\hline $\begin{array}{l}\text { Managing and negotiating health } \\
\text { care delivery systems }\end{array}$ & Nurse practitioner-patient relationship & Teaching/coaching Function \\
\hline $\begin{array}{l}\text { Analyzes the extent of mental health } \\
\text { services provided to families }\end{array}$ & $\begin{array}{l}\text { On the significance of the relationship with the patient, } \\
\text { highlights the genuine partnership and confidence }\end{array}$ & Unidentified \\
\hline
\end{tabular}

All included studies were in English, published between 2004 and 2011, conducted in Scotland - UK (one), Australia (two), The United States of America (two) and Norway (one). The studies were conducted in various scenarios, including Service or Community Mental Health Center (two), Crisis Assessment and Treatment Service (one), Unplanned Service Care (one), rural community (one) and other mental health services (one).

With regards to the publication area of the journal, they were identified as follows: psychiatric nursing/ mental health (four), community mental health (one) and qualitative research in health (one). With regard to the study design, it was found: a cross-sectional correlation study, three descriptive studies, including one quantitative and two qualitative, one hermeneutics qualitative approach and one unspecified. Thus, most studies had evidence level IV and one was not classified by the strength of evidence.

\section{DISCUSSION}

The professional in the field of Mental Health Nursing, along with other professional groups, had to adapt themselves to new ways of delivering health services, in the face of political and ideological transformations in health systems. From the perspective of the health promotion paradigm, there is a growing need for professionals to break with traditional professional boundaries and take on new roles, requiring the development of competencies for the practice of health promotion in order to search for the individual autonomy and ensure better quality of services.

Competence is defined as "the ability to apply specific knowledge, skills, attitudes and values to the standard of performance required in a particular context." Core competencies are the minimum set of competences that constitute a common basis to all functions of health promotion, with which all practitioners of health promotion should be able to work efficiently, effectively and appropriately in the field ${ }^{(14)}$.
In the area of mental health, the specific competencies needed for nursing emphasize a unique philosophy of practice to the specialty of psychiatric and mental health nursing and the needs of assisted populations ${ }^{(6)}$.

In the studies found, the following competencies were identified: Monitoring and ensuring the quality of health care practice, management of patient health/ illness status, cultural competence, managing and negotiating health care delivery systems, and the nurse practitioner-patient relationship.

A study conducted in Scotland assessed the process and results of the development of mental health services of community-based for crisis care. First, professionals' competencies were recognized and abilities needed to be strengthened in order to provide effective responses to the needs of the service user of mental health. In a second moment, an educational training was applied for mental health nurses to prepare them to take on key roles and responsibilities in the service, which was reflected in a highly positive learning experience for most participants, with indications of relevant learning to be achieved for clinical practice ${ }^{(8)}$.

The project contributed to the development of competence in the field of monitoring and ensuring the quality of health care practice, when sought to interpret their own professional forces, the role and scope of peers ability, using assessment information to improve care and practice and monitor the quality of their own practice and participate in continuous quality improvements ${ }^{(6)}$.

Assessment is one of the competencies domains for constant health promotion in the Galway Consensus Statement. Determining the scope, effectiveness and impact of policies and programs to promote health including the appropriate use of assessment and research methods to support improvement in programs, sustainability and dissemination ${ }^{(15)}$.

Research on the roles of the expanded practice of community mental health nurses indicated that they were less confident about prescribing, even though, more than half $(54 \%)$ reported that they definitely or 
probably felt confident to prescribe medication. More than $90 \%$ said they probably or definitely felt confident in making recommendations for involuntary treatment, $84 \%$ and $79 \%$ showed similar levels of confidence in ordering of diagnostic tests and in referring patients to specialist physicians, respectively ${ }^{(9)}$.

These activities represent competence in the management of patient health/illness status, which includes prescribing drugs based on efficacy, safety and cost, legally authorized and counseling on drug regimens, drug side effects and interactions with other drugs and dietary supplements; assess the results of interventions based on criteria and results, and consult or refer as needed ${ }^{(6)}$.

A similar study found that nurses and psychiatrists agreed that certain psychiatric workflows can be distributed to nurses trained to manage them. Nonetheless, interviewed nurses agreed that for independent nurse prescribing, preparation and training would be essential, beyond that provided in the current curriculum ${ }^{(16)}$.

Still regarding to competence in the management of the patient disease/illness status domain, study on how mental health workers respond to women who revealed sexual abuse, in the scenario of crisis service, showed that the participants recognized the impact of sexual abuse in long term manifestation of sexual trauma and psychiatric symptoms, highlighting the different responses in physical, cognitive, emotional and spiritual experienced by individuals. However, half of the sample did not feel confident to respond to a situation of sexual abuse $\mathrm{e}^{(11)}$.

The results demonstrated appropriate competence when analyzing and interpreting the patient's history and the information to develop appropriate diagnoses, but they showed difficulties in meeting the patient's response to lived experiences ${ }^{(6)}$.

All participants identified knowledge of the services from Center Against Sexual Abuse, as well as other specialized services for sexual abuse in the community; however, the majority of participants indicated that they rarely or never refer to these services, which denotes failure of the competence as the issue goes beyond the scope of nursing practice ${ }^{(11)}$. Among the reported barriers to working with the issue of sexual abuse, 12 participants recognized the need for containment of anxiety as a challenge, eight reported their lack of experience and/or training, and two male workers identified sex as a barrier, reflecting the cultural competence when they recognize cultural issues.

The study on the development of culturally competent "territory" care, in relation to substance abuse by teenager's rural population, indicated that the lack of integration of the family unit was presented as an etiological factor for substance abuse in adolescence. Families were conceptualized as social units charac- terized by permittivity values that were favorable to the development of these problems ${ }^{(10)}$. The study also revealed that the religion influence hindered the approach of explicit questions regarding substance abuse in youth and there were no available reference networks for professional services. Besides these aspects, socioeconomic factors and dynamics associated to gender in the Hispanic traditional culture, as the dominant male roles, were also identified as barriers to seeking help and produced negative health outcomes ${ }^{(10)}$.

Author reports that factors such as gender, geography, age and sexuality have a distinct effect on how people of the same ethnic group or from the same community experience substance abuse and the access

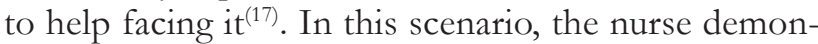
strates cultural competence, in recognizing personal prejudices and cultural issues and interacts with patients from other cultures in sensitive way ${ }^{(6)}$.

Another study evaluated the extent to which professionals of community mental health programs provides services to families of people with severe mental illness and it was indicated that the overall level of services provided to families was very low. The less frequently services reported were: provide family therapy $(2.4 \%)$, learning to identify early warning signs of relapse $(9.5 \%)$, include the family in planning the client's treatment $(10.5 \%)$, teaching methods to monitor medications $(10.8 \%)$ and refer to family support group $(11.9 \%)^{(12)}$. In this sense, the competence in the managing and negotiating health care delivery systems domain was not satisfactory because it advocates the provision of care for individuals, families and communities within the integrated health care services ${ }^{(6)}$.

Research on the experiences of mental health nurses on Emotional Intelligence in nursing practice experience highlighted the importance of genuine and authentic relationship with the patient suffering from mental health problems, essential to establish trust and confidence. Nurses highlighted the capacity for empathy and communication, as social skills needed to build positive partnership ${ }^{(13)}$.

The authors reported that the empathic capacity is the key to context awareness and understanding of the disease and suffering. Communication and dialogue make it possible for nurses to access the world of the patient's life in order to understand their suffering, which is an important base for nursing mental health professional ${ }^{(13)}$.

The respondents also pointed out the importance of supervision in the clinical development context of Emotional Intelligence, encouraging reflection, dealing with feelings, exchange experiences, participation, creativity and new ways of thinking, increased self-awareness and competence of mental health nursing ${ }^{(13)}$. 
The nurse demonstrates competence in the nurse practitioner-patient relationship domain when he/she creates an atmosphere of mutual trust and establishes partnerships with patients, communicates a sense of "being present" with the patient and provides comfort and emotional support, reflects on own emotional response to interaction with patients and uses this knowledge to further therapeutic interaction ${ }^{(6)}$.

In the selected studies, competences related to the teaching/coaching function individuals and professional role domains were not found.

The teaching/coaching function involves, from the assessment of guidance needs according to the stage of development, teaching implementation supported by his/her characteristics and learning style to the care monitoring that requires specific skills or information ${ }^{(6)}$.

In research conducted with mental health nurses, they recognized the importance of education and information to users and their families, facilitating their understanding, as an important strategy for increasing the participation of users and caregivers in the care and treatment in mental health services, highlighting, yet, the adoption of continuing education specifically guided by the needs of individuals and their caregivers ${ }^{(18)}$.

The lack of studies addressing aspects related to professional role raises reflection about the identity of the mental health nurse facing paradigmatic shifts and reorientation of psychiatric care. In this sense, authors reported that despite the efforts of universities to adequacy of the contents taught in undergraduate courses, the creation of certified courses and the inclusion of classes to discuss issues facing mental health in master's and doctorate courses, also recognize the need for specific qualification to work within the philosophical perspective of the Psychiatric Reform ${ }^{(19)}$.

\section{REFERENCES}

1. Nunes M, Torrenté M, Ottoni V, Moraes Neto V, Santana M. [The dynamics of mental health care: health professionals' signs, meanings, and practices in a Center for Psychosocial Care in Salvador, Bahia State, Brazil]. Cad Saúde Pública. 2008; 24(1):188-96. Portuguese.

2. World Health Organization. Improving health systems and services for mental health. Genève: WHO; 2009 [cited 2012 sep 01]. Available from: http://www.who.int/ mental_health/policy/services/mhsystems/en/index.html

3. Schneider JF, Souza JP, Nasi C, Camatta MW, Machineski GG. [Conceptions of a mental health team about interdisciplinary work]. Rev Gaúcha Enferm. 2009; 30(3):397-405. Portuguese.

4. Barry MM, Allegrante JP, Lamarre MC, Auld ME, Taub A. The Galway Consensus Conference: International collaboration on the development of core competencies for health promotion and health education. Global Health Promot. 2009; 16(2):5-11.

5. Bezarra Jr B. Desafios da reforma psiquiátrica no Brasil. Physis (Rio J). 2007;17(2):243-50.
No Brazilians studies were found in the search performed, considering the use of a little known document in the country, it is worth noting that health studies involving health promotion in mental health are still incipient in the Brazilian reality.

\section{CONCLUSION}

From an integrative literature review the nurses competencies for health promotion in the mental health and psychiatric context were explored, on studies published on the topic, were identified: Monitoring and ensuring the quality of health care practice, management of patient health/illness status, cultural competence, managing and negotiating health care delivery systems and the nurse practitioner-patient relationship.

The studies analysis evidenced the need for education and training so that nurses may develop the competencies of health promotion in diverse psychiatric care and mental health contexts, in order to broaden knowledge and skills.

A limitation of the study was the small number of studies on nurses competencies, with methods that produce evidence.

It is also noteworthy that the competencies were assessed from studies already published, which may not reflect the reality of health services in Brazil, therefore, we highlight the need for studies that seek to address the nurses' knowledge about the competencies in the field of mental health and its practice on health care contexts.

The results brought contributions in the sense of generating reflections between mental health nurses about the need to deep in knowledge and competencies needed to work in the perspective of health promotion.

6. National Panel for Psychiatric Mental Health NP Competencies. Psychiatric-mental health nurse practitioner competencies. Washington, DC: National Organization of Nurse Practitioner Faculties; 2003.

7. Souza MT, Silva MD, Carvalho R. Integrative review: what is it? How to do it?. einstein (São Paulo). 2010;8(1 Pt 1):102-6.

8. Hurley J, Kelly M, Mears A, Morrison C, Wiseman F. Developing unplanned care teams in Scotland: evaluating outcomes. J Psychiatr Ment Health Nurs.. 2010; 17(4):348-54.

9. Elsom S, Happell B, Manias E. Expanded practice roles for community mental health nurses in Australia: confidence, critical factors for preparedness, and perceived barriers. Issues Ment Health Nurs.. 2008; 29(7):767-80.

10. Quintero GA, Lilliott E, Willging C. Substance Abuse Treatment Provider Views of "Culture": Implications for Behavioral Health Care in Rural Settings. Qual Health Res.. 2007; 17(9):1256-67.

11. McLindon E, Harms L. Listening to mental health workers' experiences: factors influencing their work with women who 
disclose sexual assault. Int J Ment Health Nurs. 2011; 20(1):2-11.

12. Kim HW, Salyers MP. Attitudes and perceived barriers to working with families of persons with severe mental illness: mental health professionals' perspectives. Community Ment Health J. 2008; 44(5):337-45.

13. Akerjordet K, Severinsson E. Emotional intelligence in mental health nurses talking about practice. Int J Ment Health Nurs. 2004;13(3):164-70.

14. Australian Health Promotion Association's (AHPA). Core Competencies for Health Promotion Practitioners. Management Committee at their National Teleconference meeting on Thursday 5th February; 2009.

15. Allegrante JP, Barry MM, Airhihenbuwa CO, Auld ME, Collins JL, Lamarre MC et al. Domains of Core Competency,
Standards, and Quality Assurance for Building Global Capacity in Health Promotion: the Galway Consensus Conference Statement. Health Educ Behav. 2009; 36(3):476-82.

16. Jones A. Exploring independent nurse prescribing for mental health settings. J Psychiatr Ment Health Nurs. 2008; 15(2):109-117.

17. Quimby E. Ethnography's role in assisting mental health research and clinical practice. J Clin Psychol.. 2006; 62(7):859-79.

18. Goodwin V, Happell B. Psychiatric nurses' attitudes toward consumer and carer participation in care: part 2-barriers to participation. Policy, Polit Nurs Pract. 2008; 9(4): 249-56.

19. Fraga MN, Souza AM, Braga VA. Brazilian psychiatric reform: a lot to reflect on]. Acta Paul Enferm. 2006; 19(2):207-11. Portuguese. 